\title{
SCREENING EARLY MODERN IN THE SURVEY: GLIMPSES OF POLITICS AND INSTITUTIONS THROUGH FILM
}

\author{
Ralph Menning \\ Kent State University at Stark
}

Period films are as old as the industry itself and have been churned out in massive numbers. ${ }^{1}$ Most are eminently forgettable. But there are exceptions. ${ }^{2}$ This essay will argue, with reference to the early modern period, that some films do contain scenes with reasonably apt portrayals of politics and institutions. ${ }^{3}$ These vignettes make for a useful teaching tool in surveys where, by definition, time is at a premium: Because they are short, they can be fitted easily to illustrate a point that has just been made (or is about to be made). They appeal particularly to students who identify themselves as "visual learners," and can leave on this constituency a more lasting imprint than assigned reading.

A prerequisite is that students must understand that most films are made with box office receipts in mind rather than the needs of the scholarly community, and that, consequently, the producers are likely to have taken liberties with the material. For their part, instructors must remember that filmmakers need to shoehorn their subject

\footnotetext{
${ }^{1}$ A list of period films, arranged chronologically by century in which they are set, can be found at en.wikipedia.org/wiki/Historical_Films. Some film scripts are transcribed in the "Database of Movie Dialogs" at http://movie.subtitlr.com.
}

\footnotetext{
${ }^{2}$ The principal distinction between a "history film" and a mere "costume drama" was drawn by Natalie Zemon Davis, the historical advisor to the film The Return of Martin Guerre (1982; dir. by Daniel Vigne): "By history films I mean those having as their central plot documentable events, such as a person's life or a war or revolution, and those with a fictional plot but with a historical setting intrinsic to the action" (emphasis mine). "Any Resemblance to Persons Living or Dead': Film and the Challenge of Authenticity," Yale Review, 76 (September 1987), 459. Davis's categorizations are echoed in Kara McKechnie, "Mrs. Brown's Mourning and Mr. King's Madness: Royal Crisis on Screen," in Deborah Cartmell, et al. (eds.), Retrovisions: Reinventing the Past in Film and Fiction (London: Pluto, 2001), 105, and in William Guynn, Writing History in Film (London: Routledge, 2006), 2, 142. Guynn, 145146, further elaborates narrative strategies employed by filmmakers. Davis's distinctions have been criticized by Robert Rosenstone, "The Historical Film: Looking at the Past in a Postliterate Age," in Marcia Landy, ed., The Historical Film: History and Memory in Media (New Brunswick: Rutgers, 2001), 53, and by Richard Burt, Medieval and Early Modern Film and Media (New York: Palgrave, 2008), $139 \mathrm{ff}$.
}

\footnotetext{
${ }^{3}$ This essay discusses, in this order, Luther (2003; dir. By Eric Till); Henry VIII (2003; dir.by Pete Travis); The Taking of Power by Louis XIV (1966, re-released in 2008; dir. by Roberto Rossellini); Marie Antoinette (2006; dir. by Sofia Coppola); To Kill a King (2003; dir. by Mike Barker); Libertine (2005; dir. by Laurence Dunmore); Madness of King George (1994; dir. by Nicholas Hytner); Amistad (1997; dir. by Steve Spielberg); Amazing Grace (2007; dir. by Michael Apted); Barry Lyndon (1975; dir. by Stanley Kubrick); Culloden (1964; dir. by Peter Watkins); The Mission (1986; dir. by Roland Joffé); and Amadeus (1984; dir. by Milos Forman).
} 
into a running time of somewhere between ninety minutes and two hours, and that accuracy and nuance may well be sacrificed to the time allotment. ${ }^{4}$ These are, of course, not the constraints faced by academic authors, for whom accuracy must be both the first commandment and the minimum standard. Academic works are thus generally free of the canards, simplifications, and reductionism of so many films. But even purists concede that this does not guarantee accuracy in every respect: In monographs too, albeit for different reasons, the exact reconstruction of the past is only rarely possible, and the need to conjecture means that much history-writing in fact comes closer to the Italian adage "if it's not true, then it's well invented" than to Leopold von Ranke's admonition to reconstruct the past "as it actually happened."

In bygone days, when syllabi were scrutinized more for what they revealed about course content than for the breakdown of points assigned to quizzes and exams, reading assignments frequently were leavened with interpretative essays or an occasional novel..$^{5}$ It was not unusual to read a work by Stendhal or Fontane in an upper-division course on, respectively, nineteenth-century France or Germany, or to find All Quiet on the Western Front to be one of the assigned readings on the First World War in a survey. The exact reconstruction of detail mattered less to instructors than a novel's ability to stir the reader. For instance, Rubashov, the protagonist of Darkness at Noon, is a literary composite based on the lives of several first-generation Bolsheviks, but Darkness is valued by those instructors who assign it not because of biographical accuracy but because it captures so well a case of logic run amuck and pressed into the service of a totalitarian regime.

By analogy, moments from films can have similar merit. Just as novels can complement academic readings in the history classroom, movies can reinforce textbooks or monographs. By further analogy, the same method used by instructors to contextualize a literary work can be applied to evaluating a film and integrating it into the topic at hand.

\footnotetext{
${ }^{4}$ Typically, screenplays run between 4,000 (e.g., The Mission) and 8,000 words (Madness of King George, which had a prior incarnation as a stage production).
}

\footnotetext{
${ }^{5}$ Arguing on behalf of this approach, the labor historian Melvyn Dubofsky recently observed that "there are aspects of the past that we as historians can penetrate and understand only so far ... And I believe that those aspects of the past ... are often, if not always, comprehended more fully and subtly by novelists. That is why ... I have commonly used fiction-novels, short stories, creative cinema - to pique the interest of undergraduates in recent U.S. history, a time that for many of them seems as distant as that of the Greek city-states and the Roman Empire. Not that I shield students from more traditional texts, monographs, and primary documents, but fictive recreations of the past often captured their interest more fully than the more prosaic writings of historians." "Philip Roth's 'America' and Mine," Journal of the Historical Society, 10:4 (2010), 383-84. In 384 n2, Dubofsky references a contrary view that emphasizes the tension between historians and novelists: Jill Lepore, "Just the Facts, Ma'am: Fake Memoirs, Factual Histories, and the History of History," The New Yorker, March 24, 2008.
} 
Naturally, whatever meaning might be derived from a film scene-never mind the question what might or might not be screened - depends on the goals of the course. In the portion of my survey that deals with the early modern period, one objective is to establish these centuries as constituting a distinct era, demarcated at one end against medieval and, at the other, against modern. (The course, later on in the semester, goes on to characterize modern as rooted in a rebellion against the practices of early modern.) The course is heavily "political," and therefore the film segments discussed here are suited to draw attention to political structures and practices.

The politics of religion, constitutional politics, the Atlantic economy, and the warfare of the early modern era all stand out as distinctive. In its discussion of the politics of religion, the course contrasts the medieval monopoly on faith exercised by the Roman church in western and central Europe with the widespread acceptance of the formula whose reign, his religion (cuius regio eius religio) of early modern, and with the modern separation of church and state. In its consideration of constitutional politics, it juxtaposes absolutism-always aspired to but never completely attainedin early modern with the notions of we, the people and liberté et égalité of modernity. In its discussion of the Atlantic economy (apart from the Vikings and perhaps Breton or Portuguese fishermen in the Grand Banks, there was only coastal trade in the Middle Ages), the course compares the Columbian exchange (early modern) with the decline of slavery, sugar, and indigo in the nineteenth century and their replacement by wheat, meat, investment flows, technology transfers, and financial crashes (modern). In its analysis of war, baronial armies and mercenary companies (medieval) are silhouetted against religious wars, trade wars, and wars of succession (early modern) and, ultimately, ideological wars fought by conscripts (modern).

Within this framework one can discover the "texture" of early modern-the institutions, processes, principles, and "best practices" that could be labeled "typical" of the period. But a word of caution is in order: As much as the categorization and classification of events helps us to identify patterns and trends, history is more than an exercise in taxonomy. Each of the clips discussed here also deserves to be studied on its own merits; each has its own vitality. In the aggregate, these scenes form the kaleidoscope of colors, schemes, ingenuity and intrigue, plots and complexities that is life itself.

\section{Reformation}

In three successive scenes, the 2003 film Luther relates the immediate background to Luther's protest against Rome. In Scene 6 ("Savior of the Church," 3 minutes, 57 seconds running time), Pope Leo $\mathrm{X}$ and the papal nuncio Aleander narrate Albrecht of Hohenzollern's bid for the archdiocese of Mainz, then the largest see in Europe, and Albrecht's need to recoup the sum demanded by Leo for his approval of the investiture. In Scene 7 ("The Price of Salvation," 5:43), we are treated to the skills displayed by Albrecht's chief fund-raiser Johann Tetzel. Tetzel's expertise in selling 
indulgences ("as soon as a coin in the coffer rings, the soul from purgatory springs") makes for a moment that no communications major can fail to appreciate. His marketing blitz is, of course, the catalyst that brings to the fore Luther's long-standing doubts about "free will," the Roman church's core doctrine. Scene 8 "Papal Politics," 2:55), recreates the reception of Luther's 95 Theses on the Power and Efficacy of Indulgences by Albrecht and in Rome.

The political, rather than the doctrinal, background to the English Reformation is highlighted in Henry VIII. Henry still enjoys celebrity status outside of the classroom, as most first-year students even before signing up for the survey seem to have heard of the king's unusually high testosterone level. But the merit of Scene 2 ("The Spanish Queen," 4:02) is that it highlights Henry's concern for the continuance on the throne of the House of Tudor. Given that by 1520 his only legitimate child was his daughter Mary, given that England had never been ruled by a reigning queen, and given the absence of a son born in wedlock, Henry could not discount the possibility that some aristocrat, descended in direct male line from the younger son of some earlier king, would dispute the legitimacy of Mary's succession and claim the throne for himself. Any such claim harbored the possibility of civil war. Scene 2 conflates two episodes to make precisely these points: The scene relates Henry's attempt to legitimize his bastard son Henry Fitzroy (which, if successful, would have put Henry Fitzroy first in line for the throne) and tells the story (or at least hews to Henry's version) of the contumacy of Edward Stafford, Third Duke of Buckingham, who allegedly planned an aristocratic rebellion against the king.

\section{Early Modern Courts and Constitutions}

The great fashion in seventeenth-century constitutional politics was absolutism, i.e., the expansion of the powers of the monarch at the expense of other stakeholders, notably the aristocracy. In Roberto Rossellini's The Taking of Power of Louis XIV, we meet the young king in 1661, determined, on the death of his chief minister, Cardinal Mazarin, to centralize power in his own hands. ${ }^{6}$ In Scene 6 ("The Queen Mother," about 0:50 into the scene for 4:20), Louis develops his rationale for so doing and speaks of the necessity to forestall a revival of the fronde, the series of aristocratic rebellions

${ }^{6}$ The early scenes of the film focus on Mazarin's final illness. They are notable for their depiction of early modern medicine and also for their conscious imitation of seventeenth-century chiaroscuro effects. This latter point was stressed by Jean-Dominique de La Rochefoucauld, a screenwriter and the historical adviser to this film, in a 2004 interview. Cineastes should not miss the interview, which can be found in the special features section of this DVD. 
that had roiled the land a decade earlier. ${ }^{7}$ But even if the king resolved to be his own minister, this ambition had its physical limitations, and he needed a factotum to execute his program. His new comptroller-general of finances, Jean-Baptiste Colbert, proved a willing accomplice and hastened to portray the king as the fount of all power, privileges, favors, and benefits (2:20 into Scene 12, "Arrest and Strategy," for 2:50). ${ }^{8}$ In its depiction of the measures to be taken, this scene neatly captures the essence of dirigisme (although the term itself is never used), the philosophy of state-sponsored interventions which are a hallmark of the French economy still.

If the dominant theme in early modern constitutional politics was absolutism and its model was the French monarchy, then its brick-and-mortar embodiment was Versailles. Sofia Coppola's Marie Antoinette captures the atmospherics of palace life: stultifying boredom amidst sumptuous luxury. Scene 4 ("Versailles," 4:10) contrasts the hostility of the court to the new dauphine with the stunning louis-quinze elegance of her new apartments. The case for Versailles as a golden cage-for the aristocracy as well as the new arrival from Vienna-is brilliantly made in Scene 6 ("Wedding Night," 3:54). Detailing the meaningless ritual of the morning levée, this scene dovetails with W.H. Lewis's famous description of precisely this routine in his Splendid Century, and can be used effectively as a visual companion piece to this excerpt. ${ }^{9}$

The English constitutional aberration- the early defeat of absolutism and the growth of the powers of parliament- has lately been well served by three feature films. To Kill a King tells the story of the English civil war from the perspective of Sir Thomas Fairfax, Cromwell's predecessor as captain-general of the parliamentary army. In Scene 6 ("Traitor"), Fairfax tries to persuade an obstinate Charles I to yield to parliament: He accomplishes the exact opposite, as Charles rejects any modus vivendi and instead uses this opportunity to launch a vigorous defense of divine-right kingship

\footnotetext{
${ }^{7}$ Students should be aware that the term parlements (the courts of appeal that were a stronghold of the aristocracy) is, in the captions, misleadingly translated as "parliament."

${ }^{8}$ Colbert owed his advancement to the fall of Nicolas Fouquet, who had been tipped to succeed Mazarin. Fouquet's chef, François Vatel, after the disgrace of his patron, entered the employ of the Prince of Condé. More an impresario than a chef for the Condé household, Vatel in 1671 staged a three-day entertainment for Louis XIV, and wined and dined more than 2,000 guests at a cost of 600,000 écus. This party became the subject of Vatel (2000, dir. by Roland Joffé). Like The Return of Martin Guerre, Vatel does not yield the stand-alone moments which are the concern of this essay, and the film has to be viewed in its entirety. But it is likely that Vatel was inspired by Rossellini's Louis XIV, where in Scene 15 ("A Meal at Versailles," 2:40 into the scene for 8:50) we are treated to a similar behind-the-props view of the royal kitchens, with scores of attendants bowing to the roast ("la viande du roi") as it is paraded by on its way to the royal table. What is anachronistic, however, is that Louis did not move his court to Versailles until 1682.
}

${ }^{9}$ W.H. Lewis, The Splendid Century: Life in the France of Louis XIV (1953; reprint, 1997), 40-42, 4849. 
(5:00 minutes into Scene 6, for 1:30). Denying parliament the authority to try him, Charles further fleshes out the argument on behalf of absolutism in Scene 10 ("Trial," 3:15 minutes into the scene for $1: 35$ ).

It's hard to look past the foul language in Libertine (so this movie is not for the faint-of-heart), but the obscenities are probably "in character." John Wilmot, Second Earl of Rochester-high-ranking aristocrat, poet, and favorite of the restoration king Charles II-freely indulged in every excess of the age. But the film also features two serviceable snapshots of the politics of the restoration monarchy. Set in a London theater (given Charles II's weakness for stage actresses, the backdrop serves as a potent symbol for the restoration monarchy), the first five minutes of Scene 5 ("The Royal Figure Beckons") speak to the predicament of a king with empty pockets. Barely ten years into the reign, says Charles,

The country is on the brink. People are still reeling from the fire and the plague. The Catholics are plotting. The Dutch are a bunch of bastards and the French are ten times worse, and there is no money. I can only have funds by calling in a parliament plotting against me. And I don't want to walk out of this without my head on, the way my father did.

This soliloquy in itself could serve as a point of departure for a wide-ranging discussion on the condition of restoration monarchy in the late 1660s. In the film, Charles implores Rochester, "if you took your seat in the Lords you could make great speeches that would influence events." Rochester finally delivers in Scene 20 ("Saving the Monarchy," 5:00). Horribly disfigured by syphilis, he convinces the Lords to vote against a resolution that would have barred Charles's younger brother James from the throne.

The eighteenth-century English constitutional peculiarity was that sovereignty resided not in the king and his conscience (the absolutist model) but in the "king-inparliament." It is the allocation of powers among the three institutions that determined policy-monarch, prime minister, and parliament-that forms the subtext to Madness of King George. The film (Scene 1, "Appearances," 8:02) begins in medias res with the throne speech of 1788. Against the backdrop of the speech, an exchange between Prime Minister William Pitt and Charles James Fox, who covets Pitt's job and enjoys the favor of the Prince of Wales, begins to explain the symbiotic relationship between king and prime minister.

[Fox:] You see that the king did not write his own speech, Mr. Pitt. [Pitt:] The king will do as he is told, Mr. Fox.

But the prime minister was still appointed by the monarch on the expectation that he could deliver majorities in parliament and served as his sufferance. A new king was under no obligation to retain his predecessor's minister. Towards the close of the 
scene, the king tells Pitt, 'You're my prime minister. If anything happened to me, you'd be out and Mr. Fox in."

The same point is reiterated by Pitt (Scene 4, "Could he be ill?" 4:50), as he contemplates the looming mental incapacity of George III and the prospect of a regency by the Prince of Wales in the absence of the king: “... we [i.e., his ministers] live in the health and well-being of the sovereign as much as any vizier does the sultan."

In the event of a regency, the Prince of Wales would appoint Fox prime minister. An artfully crafted dialogue, however, suggests that apart from a craving for power the two political allies had few objectives in common (Scene 4):

[Fox:] King in all but name!

[PoW:] With all the powers.

[Fox:] Subject to parliament.

[PoW:] Charles, don't quibble.

[Fox:] And certainly ... all the funds.

[PoW:] Just think of it.

[Fox:] Regent!

[PoW:] Prime minister!

[Fox:] America forgiven.

[PoW:] London rebuilt.

[Fox:] Parliament could be reformed.

[PoW:] A palace on Primrose Hill.

[Fox:] The slave trade abolished.

[PoW, rolling his eyes:] Oh, yes. All that, too.

Despite its brevity, the dialogue paints a skillful portrait of the two men: Roués both, George Augustus and Charles James Fox nonetheless had rather different political sensibilities and a rather different sense of the purposes to which their new power should be applied.

Scene 4 and especially the latter part of Scene 8 ("Voted Incapacitated?" 2:17 into the scene to show the next 2:38) teem with the wheeler-dealers, opportunityhunters, patronage-seekers, and aristocratic dandies who constituted the bulk of parliament. In characterizing his parliamentary colleagues to the Prince of Wales, Fox has few illusions about

... the nation's representatives. Some come to Parliament in the hope that they might serve their country. But most of them, being human, are here to fill their pockets. Pitt and your father have done them very well ... pensions, places, bribes. Once it is plain that Pitt is finished and there is no more swill in the trough, Your Royal Highness will be made regent (Scene 8). 
As the camera pans this crowd, the viewer cannot help being reminded of Hogarth's Humors of an Election: The faces are a satirist's bonanza and a feast for the phrenologist.

One further facet to this film deserves mention here-this time, a reference to German constitutional history. In the opening scene, the viewer is treated to a snippet in a conversation between Frederick, Duke of York and the second son of George III, and the Prince of Wales. In this aside, 25-year-old Frederick tells his brother that, very much to his own surprise, he has just discovered that he has been made bishop of Osnabrück. The producers of the film took some liberties here, as Frederick had in fact been made prince-bishop before his first birthday and was probably the record-holder as the youngest person ever invested with a bishopric. Long story short, the Peace of Westphalia of 1648 stipulated that the prince-bishopric of Osnabrück, a territory with a mixed Catholic and Lutheran population where the bishop was also the ruler, would alternate between a Catholic and a member of the (Lutheran) House of BrunswickHanover, the dynasty that took the English throne in 1714. In the century and a half between 1648 and 1803 (when the bishopric was snuffed out by the secularization of church lands in Germany), Catholics and Lutherans swapped the see of Osnabrïck five times. But Frederick's 39 years at the helm made him the longest-serving bishop, if only in name, in the 1,000-year history of the diocese.

\section{Atlantic economy}

Amistad is Steven Spielberg's chronicle of the slave rebellion in 1839 on the Spanish-owned vessel Amistad, the docking of this ship in New Haven, Connecticut, and the legal wrangling that ensued. By 1839, the slave trade was illegal and clandestine (though neither in the Spanish empire nor in the U.S., slavery itself). However, little had changed in the "mechanics" of the trade since its heyday in the seventeenth and eighteenth centuries. These practices are depicted in a harrowing sequence towards the middle of the film (Scene 11, 9:18), which evokes the horrors of the Middle Passage. The effect is heightened for the audience because, like the African captives on board, we are never given any reason for the arbitrary sadism of the crewbut then random brutality is one of the classic instruments of terror. Students should note that this part of the film is set on a Portuguese vessel: Because of the 1494 Treaty of Tordesillas, which forbade new Spanish colonization in West Africa, Spain was a recipient but not a supplier in the trans-Atlantic slave trade.

Amazing Grace treats the life and times of William Wilberforce, the principal campaigner in Britain against the slave trade. Wilberforce inspired the legislation, finally passed in 1808 , that prohibited the participation of British subjects in the trade. The film has its incongruities - it depicts the Duke of Clarence (the future King William IV and also a younger son of George III) as sitting in the Commons and erroneously elevates Charles James Fox and Banastre Tarleton, a member of parliament for 
Liverpool, to the peerage. ${ }^{10}$ Tarleton's life and career in themselves would make for an interesting, if unedifying, subject for a film, but his seething contempt for abolition in Scene 13 ("Voice of the People," 4:00) would be more understandable if the film had identified him as the son of a Liverpool slave trader and Liverpool as the foremost home port for British slavers. Nonetheless, this scene is worth watching for a rehash of arguments against abolition and the strength of the forces against which Wilberforce had to contend. It also brings to the fore the widespread aversion in the Commons to the notion of "the people" (in Tarleton's phrase, the "rule of the mob"). Woven into the next scene (Scene 14, "Two Pistols," 6:00) are allusions to the power of the West Indian planters' lobby and to the endemic corruption plaguing the House of Commons. Both factors are part of the mix in the backstage maneuverings of both abolitionists and anti-abolitionists, as they vie for the support of the Home Secretary, Lord Henry Dundas. Dundas's prevarications might seem morally repugnant, but for students there is an additional message: They are in character with what is, for better or for worse, the great theme of eighteenth- and nineteenth-century British constitutional politics, gradualism.

\section{Early Modern War}

Stanley Kubrick's Barry Lyndon is named for the eponymous anti-hero of Thackeray's nineteenth-century Bildungsroman, set in the Seven Years' War and its aftermath. The second half of the film is highly instructive as a social history of what must be done to obtain a peerage. It is visually lavish: Its candlelit scenes and grouping of characters at card tables, in libraries, at an art dealer, in the anterooms of country houses affect the style of eighteenth-century English painting and should be mandatory viewing for any upper-division course on the early modern era. But it is too long to show in a survey. What $i$ s suitable for a survey is a battlefield scene in the first half (Scene 14, "First Taste of Battle," 3:00). Even though the scene is questionable in some of its details (the volleys are too rapid and we never see troops cleaning or reloading their muskets), it does convey the attributes of eighteenth-century warfare: uniforms, some standardization of equipment, advancing in line-all of which necessitated drill and the ruthless discipline for which eighteenth-century armies were notorious. Barry himself, Irish and destitute, is the archetypical cannon fodder favored by eighteenth-century recruiters and cameralists whose preference for foreign mercenaries over press-ganged natives was dictated by the wish to avoid manpower shortages in farming and manufacturing.

\footnotetext{
${ }^{10}$ Truly incongruous is Scene 3, a flashback to the early 1780 s, which shows both Clarence and Tarleton seated in the Commons. At the time, Clarence was still in his teens and Tarleton served as a British officer in the American War for Independence.
} 
The unsurpassed depiction of early modern warfare in Peter Watkins's 1964 film Culloden, which chronicles the decisive defeat, in the Scottish highlands in 1745, of forces loyal to Charles Edward, the Stuart claimant to the Scottish and English thrones, and English retribution. A BBC "documentary reconstruction," the film is done interview-style, with reporters scurrying around the battlefield; commanders and rankand-file alike speak directly into the camera. This technique is calculated to produce, in the mind of the viewer, the kind of "alienation effect" familiar from Bertolt Brecht's plays - wherein catharsis is arrested and embedded in an analysis of the larger social context. The seventeen minutes after the opening panels are especially valuable for a course that seeks to demarcate early modern as distinct: The clash in the highlands is quintessentially a face-off between an early modern army (again: uniformed, somewhat standardized, disciplined, paid) and the feudal system of the highland clans, in which service is based on land tenure and obligation, with unpaid warriors brandishing anything they could find that might inflict bodily harm on the enemy. ${ }^{11}$

\section{Enlightenment}

The 1986 film The Mission, in its treatment of the eighteenth-century Latin American frontier, offers a visually sumptuous contrast between baroque ideas of spatial order and the jungle wilderness of the upper Paraná basin. Its subject is the fate of the Jesuit reductions east of Paraguay, a safe haven for Guarani Indians from Spanish indentured labor and Portuguese slavery. By the terms of a territorial swap enshrined in the 1750 Treaty of Madrid, the reductions were to be transferred from Spain to Portugal (the core political message stretches from Scene 15, "The Cardinal Arrives," into 1:35 of Scene 19, "Cardinal's Conscience," for a total of 21:47). For the missions, the transfer was tantamount to disestablishment (with the prospect of slavery for the population), as Portuguese policy had become notoriously anti-clerical and anti-Jesuit. It was shaped by the court favorite and chief minister, the Marquis de Pombal, who prided himself on his "enlightened" credentials, which, among other things, meant opposition to the church. The story is related from the perspective of the papal emissary to Asunción, who, with resignation in his voice, concedes to the Portuguese negotiator: "You serve the Marquis of Pombal, who is insanely hostile to the church and unfortunately rules your king [Scene 18] ... He is determined to destroy the power of the church [Scene 19]." The Portuguese man-on-the-spot wryly shifts the premise of the argument: "And your Christian community is commercially competitive?" The cardinal's reply_-It's very prosperous. Isn't that precisely why you want to take it over?"-plays on the desire of enlightened monarchs and ministers to increase

\footnotetext{
${ }^{11}$ Nicholas Cull, "Peter Watkins's Culloden and the Altemative Form in Historical Filmmaking," in Carmell, et al. (eds.), Retrovisions, 91.
} 
revenues. The missions might not have been targeted, the Portuguese emissary suggests with some irony, had they been less successful:

You should have achieved [in the reductions] a noble failure if you wanted the approval of the state. There is nothing we like better than a noble failure. It's deeply reassuring to a trading nation such as my own (Scene 19).

The reply echoes (and broadens) Garrett Mattingly's throwaway line comparing the Portuguese overseas empire to a "bankrupt wholesale grocery business, which was what the King of Portugal's oriental [sic] empire had somehow turned into."12

The episode of the Jesuit missions might not be the central narrative of the enlightenment, but it speaks directly to the darker side of two enlightenment themes-the attack on organized religion and the attempts of "enlightened monarchs" to increase the efficacy of state power. In cultural terms, however, The Mission is worth noting for another reason: It proved a major impetus for a revival of interest in baroque Latin America, in particular the music of the reductions. ${ }^{13}$

Two scenes in Milos Forman's Amadeus (Scene 6, 2:19, and Scene 8, 3:55) highlight the culture wars that accompanied the enlightenment in Central Europe-to wit, the effort to reestablish German-language drama and to emancipate German opera from Italian and French models. Earlier German-born operatic composers-Handel, Hasse, Gluck - had set to music libretti in languages other than German, but the first major German-language opera was Mozart's Abduction from the Seraglio, commissioned specifically by the Habsburg Emperor Joseph II as a work to be performed in German. A further sign of imperial favor was that Abduction premiered at the theater of the Vienna court (the old Burgtheater, taken down in the 1880s), a building connected-literally, via a skyway - to the imperial apartments. As the scene makes abundantly clear, the imperial commission matched Mozart's own tastes. A cosmopolite through and through, Mozart nonetheless thought of himself as Germanwitness his mocking exclamation, in a letter dated March 1785, "and wouldn't that be

\footnotetext{
${ }^{12}$ Garrett Mattingly, The Armada (New York, 1959; reprint, 2005), 128. Also see, Bailey W. Diffie and George D. Winius, Foundations of the Portuguese Empire, 1415-1580 (Minneapolis: University of Minnesota Press, 1977), 312ff and 415ff. For correctives, see A.J.R. Russell-Wood, The Portuguese Empire, 1415-1808 (Baltimore: The Johns Hopkins University Press, 1998), ch. 4, passim, and C.R. Boxer, The Portuguese Seabome Empire, $1415-1815$ (New York: Knopf, 1969), 148: “... by 1700 Brazil was clearly the most profitable jewel in the Portuguese crown." Similarly, Boxer, 175, 192-93.
}

\footnotetext{
${ }^{13}$ For instance, "Bolivian Mission Towns Revive Baroque Legacy" (May 15, 2008), www.npr.org/templates/story/story.php?storyId $=90321843$ or the site for the music ensemble www.florilegium.org.uk.
} 
a permanent stain for Germany if we Germans seriously began to think German, behavd German, speak German, perhaps even sing in German?!"14

Indeed, Amadeus's two scenes also serve as a fitting coda to early modern: Throughout the early modern era, identity had been defined by religion, loyalty to a prince, membership in a corporation, or even-in Eastern Europe-serfdom, whereas in modernity the bond between individuals and their community was to be based on language.

Several weeks of exposure to early modern usually have the side-effect of establishing the period, in the mind of students and instructor alike, as an age of absurdities. Perhaps this is unfair. Absurdity is the hallmark of all aging societies where entitlements, once given, are impossible to revoke-watching this evening's network news can leave the viewer with the same impression of the here and now. But among enlightenment writers, it became a sport to pillory the irrationalities of the early modern political order. Montesquieu, in his Persian Letters, invented fictional Persian travelers who reported back to their countrymen on the nonsensical nature of daily life in France; Voltaire's Candide inhabited a world of grotesque perversions; Goethe, who clerked at the appeals court of the Holy Roman Empire for four months in 1772, recalled that some 20,000 cases clogged the understaffed and underfunded court, which processed these at an annual rate of about sixty.

Which features of early modern times get to the top of the catalogue of absurdities very much depends on the inclinations and political tastes of the instructor, and, in the screening of films, on the availability of the subject. The films detailed here offer glimpses of the court ceremonial at Versailles, the uses of the bishopric of Osnabrück for political barter, the press-ganging of foreign mercenaries, and the slave trade. All these scenes suggest that film is an excellent medium for chronicling processes and practices. They also convey the flavor of early modern as an assemblage of absurdities. For future filmmakers, there is no shortage of subjects to make this point further, and they might well discover rich material in the Manila galleon, the Dutch tulip craze of the $1630 \mathrm{~s}$, or the sexual antics of Augustus the Strong. Some absurdities might not even require a film, as we have excellent visual evidence from the age itself: Portraits by Anthonis Mor, Hans von Aachen, Velazquez, and Miranda amply confirm prognathia, the genetic deformation of jaws, nose, and lips that invariably accompanied generations of intermarriages amongst Trastámaras and Habsburgs. In this instance, a film might not be necessary-an old-fashioned slide-show would suffice.

\footnotetext{
${ }^{14}$ Mozart to Anton von Klein, 21 March 1785. A month after the premiere of Abduction, Mozart had written his father, "... If Germany, my beloved fatherland, of which, as you know, I am proud, will not accept me then in God's name let France or England become the richer by another talented German, to the disgrace of the German nation. You know well that it is the Germans who have always excelled in almost all the arts. But where did they make their fortune and their reputation? Certainly not in Germany! Take even the case of Gluck. Has Germany made him the great man he is? Alas, nol" Mozart to Leopold Mozart, 17 August 1782.
} 